\title{
Biomass char production at low severity conditions under $\mathrm{CO}_{2}$ and $\mathrm{N}_{2}$ environments
}

\author{
G. Pilon \& J.-M. Lavoie \\ Université de Sherbrooke, Canada
}

\begin{abstract}
In a perspective of biomass value addition, biomass char, a thermochemical product, long time considered as a residue, is now getting attention and may represent a vector in the sustainability of the whole biomass sector. Some char types were shown to have great potential as a solid fuel or precursor for further transformations as well as having attributes for storage and transportation. Other types showed potential as a soil carbon sequestration technique and soil amendment enhancing biomass yields. Depending on several factors, but mostly on biomass and production conditions, biomass char physico-chemical characteristics may vary tremendously. Therefore, in order to be used in accordance for specific utilizations, its characteristics must be carefully understood and controlled. In this study, chars with varying properties were produced in a custom-made lab-scale fixed bed reactor. Along these experiments, various biomass chars were produced under $\mathrm{CO}_{2}$ and $\mathrm{N}_{2}$ for temperatures of 300 and $500^{\circ} \mathrm{C}$. Char was produced from switchgrass (Panicum virgatum L.) an energy crop grown in Canada. It was then characterized for ultimate and proximate analysis as well as for calorific value. In addition, specific surface was characterized by Brunauer-Emmett-Teller (BET) technique. Char organic content composition was verified by Soxhlet extractions using dichloromethane and extracts were analysed by GC-MS.
\end{abstract}

Keywords: BET, biochar, biomass, bio-oil, char, $\mathrm{CO}_{2}$, pyrolysis, torrefaction.

\section{Introduction}

Biomass char refers to biochar with respect to soil amendment, and to charcoal when referring to the charred organic matter used as a source of energy $[1,2]$. The latter has been shown to be a potential soil amendment that would enhance 
biomass production/hectare. It was also shown to have positive effects on soil health as well as being able to store carbon for reduction of $\mathrm{CO}_{2}$ emission $[3,4]$. Another application, potentially complementary to soil amendment [5], stated that biomass char also had potential to provide the required heat for pyrolysis' endothermic reaction along bio-oil production. Furthermore, it was shown to be advantageous as a feedstock for combustion or for syngas production through gasification $[6,7]$.

Biomass char can be obtained through different thermochemical processes operating at low oxygen content using varying degrees of severity. In chronological order of severity, torrefaction, slow and fast pyrolysis and gasification are processes under which biomass char can generally be obtained. Torrefaction can be defined as the conversion of lignocellulosic material occurring without oxygen, within a temperature range of 200 to $300^{\circ} \mathrm{C}$ at atmospheric pressure [7, 8]. It consists mostly of hemicellulose degradation resulting in a solid material with low moisture content, hydrophobic properties and high calorific value if compared to original biomass. Most likely, biomass char obtained under torrefaction may not meet biochar stable soil characteristics since original biomass requires sufficient temperature $\left(\geq 300^{\circ} \mathrm{C}\right)$ in order to produce carbonized material with modified chemical bonds, which are less likely biodegradable [2]. Slow pyrolysis operates usually at temperatures between 300 and $500^{\circ} \mathrm{C}$, at heating rates lower than $2{ }^{\circ} \mathrm{C} / \mathrm{s}$ and long residence time (min to days), conditions that were shown to enhance char production over noncondensable gases and oil. Fast pyrolysis operates at higher heating rate (up to $\left.10000^{\circ} \mathrm{C} / \mathrm{s}\right)$, shorter residence time ( $<1 \mathrm{~s}$ to $30 \mathrm{~s}$ ) and enhances biooil over char and non condensable gases yields $[9,10]$. Gasification conditions operate with low-mid level of oxygen, yielding generally up to about 5-10\% biomass char. Despite their lower char production yield compared with slow pyrolysis, the potential of fast pyrolysis and gasification char were recently considered as having a soil amendment potential [9].

Biochar physico-chemical properties vary to a large extent depending on a multitude of factors, especially the reacting conditions at which it is prepared [11]. The operating parameters that have been reported to influence its properties are the heating rate, the highest operating temperature, the pressure, the reaction residence time, the reactor design, the biomass pretreatments, the flow rate of inputs and the post treatments [12]. Among these numerous factors, temperature is considered one of the most important affecting char properties as it provides the necessary activation energy of the implied reactions, furthermore it influences physical changes as volatilization and structural melts. Studies on wood showed that the three main biomass components have been reported to decompose at temperature ranging from $200-325^{\circ} \mathrm{C}$ for hemicelluloses, from 240 to $375^{\circ} \mathrm{C}$ for cellulose and from 280 to $500^{\circ} \mathrm{C}$ for lignin $[8,12]$. Demirbas [13] studied carbonization (medium rate pyrolysis at $10^{\circ} \mathrm{C} / \mathrm{s}$ ) for several agricultural and forest residues, for temperatures ranging from 300 to $900^{\circ} \mathrm{C}$. For every feedstock, solid products were found to decrease, gases increased and liquid fractions decreased, furthermore, higher heating values (HHV) were also found to increase for increasing temperature. 
Pyrolysis gaseous environment also plays a major role. Conventionally, pyrolysis operates within an environment free of oxygen, therefore using inert gases such as nitrogen. $\mathrm{CO}_{2}$ is also an inert gas at room temperature, however, increasing temperature, $\mathrm{CO}_{2}$ becomes reactive and tends to react with carbon char through the reverse-Boudouard reaction:

$$
\mathrm{C}+\mathrm{CO}_{2} \rightarrow 2 \mathrm{CO}
$$

There are numerous thermochemical processes that could take beneficial advantage of using $\mathrm{CO}_{2}$. In combustion field, especially in coal industry, the Oxyfuel Technology which consists of using flue gases with pure oxygen $\left(\mathrm{CO}_{2}\right.$, $\mathrm{H}_{2} \mathrm{O}$ and $\left.\mathrm{O}_{2}\right)$ instead of air $\left(\mathrm{N}_{2}, \mathrm{O}_{2}, \mathrm{CO}_{2}\right.$ and $\left.\mathrm{H}_{2} \mathrm{O}\right)$ appears as a promising technology especially from $\mathrm{CO}_{2}$ output purity and sequestration point of view [14]. In addition, use of flue gases as a gas source contains residual heat which is beneficial for energy flows within the overall process [15]. In gasification, use of $\mathrm{CO}_{2}$ to enhance Boudouard reaction and $\mathrm{CO}$ formation for syngas production is also a common practice. In physical activation of char for activated carbon, $\mathrm{CO}_{2}$ is the medium used for surface area and pore enhancement. Physical activation is usually done at temperature around 900 to $1200^{\circ} \mathrm{C}$ [16]. In the presence of $\mathrm{CO}_{2}$, char yield is usually reduced towards formation of volatiles [15, 17]. Jindarom et al. [16] observed that for temperatures around 350 to $750^{\circ} \mathrm{C}$, the use of $\mathrm{CO}_{2}$ in comparison of $\mathrm{N}_{2}$ resulted in chars with higher char specific surface and basicity levels.

High specific surfaces as well as high porosity are two desired characteristics for soil amendment applications since it may represent a favourable site for beneficial microorganisms' proliferation as well as an exchange surface for nutrient retention or water absorption attributes [1]. Under pyrolysis conditions, specific surface was observed to reach peak values at temperatures varying from 350 to $700^{\circ} \mathrm{C}$ depending upon a few factors, such as biomass types $[2,18]$. Decrease in specific surface area at higher temperature was attributed, by some researchers, to melts in char structure. Increasing retention time was also shown to increase porosity since it allowed most volatilization reactions to reach completion. As for the heating rates, lower heating rates would allow volatile release with less morphological changes, therefore maintained natural porosity in comparison with higher rates which would even lead to morphological transformation of cell structure [12].

In this research, char was prepared from switchgrass (Panicum virgatum). Switchgrass was chosen due to its beneficial characteristics as an energy crop such as its hardiness in harsh climate conditions and poorer soils $[19,20]$. In a first step, a homemade fixed bed reactor was tested under specific conditions simulating a high heating rate reactor operating under $\mathrm{N}_{2}$ atmosphere. In a second step, the same reactor was then operated at lower heating rate, but adding new atmosphere conditions, first under $\mathrm{N}_{2}$ and secondly under $\mathrm{CO}_{2}$. Temperature, heating rate and gas atmosphere were the two main parameters studied and their effect on char physico-chemical characteristics was analysed. The char obtained was characterized for proximate and ultimate analyses, for BET as well as for its calorific value. Some of the chars organic content compositions were verified by Soxhlet extractions using dichloromethane and 
extracts were analysed by GC-MS. Bio-oil yield was also verified and the ones from slow heating rate were analyzed by GC-MS.

\section{Materials and method}

\subsection{Biomass}

Switchgrass (panicum virgatum) Cave-in-Rock species utilized for the experiments was grown in the Eastern Township region of Quebec, Canada. The crop was grown in a clay soil and had a 1.5 years root system. The feedstock was harvested in Fall (November 2009) at moisture content below 10\% in $500 \mathrm{~kg}$ bales and stored in open structures protected from rain. Switchgrass samples used for experiments were maintained in unsealed plastic bags at room temperature $\left(20-25^{\circ} \mathrm{C}\right)$.

\subsection{Experimental setup}

For experimentations, a lab scale fixed bed pyrolysis reactor was used. It consists of a stainless steel (SS) cylindrical reactor of $26.6 \mathrm{~mm}$ ID and $0.44 \mathrm{~m}$ length installed in a $2400 \mathrm{~W}$ electric tube furnace mounted vertically. Biomass is added to the reactor using a biomass carrier, fig. 1 . The latter is $13 \mathrm{~cm}$ long, $25 \mathrm{~mm}$ OD in diameter and is made of stainless steel. Carrier's top, bottom and along the length is partially opened in order to allow gas flow through its structure. A wire mesh is installed within the carrier to retain the biomass from falling down. The reactor's entrance is controlled via a gate valve equipped with a motor for a quick control.

During the initial experiments operating at higher heating rate, a preheater installed underneath the reactor was used in order to preheat the biomass carrier at reactor's temperature. The carrier has a top opening in order to fill it with biomass. The action of filling the reactor and taking it into the reactor is done for every test in less than $10 \mathrm{~s}$. During the second step of experiments, at lower heating rates, a preheater for biomass carrier was not used. The biomass carrier is attached to a thermocouple $(\mathrm{T} / \mathrm{C})$, which serves as a rod to move it into the reactor. The $\mathrm{T} / \mathrm{C}$ also provides an indication on temperature progress within biomass carrier.

Nitrogen and carbon dioxide are the two gas vectors utilized while also serve to enhance heat and mass transfer between gases and feedstock. Gas flow input is maintained at $0.115 \mathrm{~L} / \mathrm{s}$ (STP: $101.3 \mathrm{kPa}-$ and $25^{\circ} \mathrm{C}$ ) for every test and is controlled by a flowmeter before entering the reactor. The flowmeter is calibrated with respect to each gas. Nitrogen gas and $\mathrm{CO}_{2}$ are respectively preheated before entering the reactor using an inline gas heater and while passing in the annulus region between reactor and tube furnace. Gases and volatiles exiting the reactor pass by a heated line maintained around $200 \pm 25^{\circ} \mathrm{C}$ before being diverted to an exhaust system.

For pyrolysis vapours' mass balance, vapours are collected within two consecutive glass condensers; both are kept within isothermal container filled 
with dry ice. Pyrolysis gases are obtained by difference from char and condensable liquid yields.

Real time temperature monitoring is done on the overall system using National Instrument Data Acquisition System NI cDAQ-9172 equipped with Labview software. Thermocouples are positioned all over the system as shown in fig. 1. In fig. 1, $\mathrm{T}$ corresponds to thermocouples, where $\mathrm{T} 1$ refers to biomass carrier, T2 to gas outlet, T3, T4 and T5 to annulus region between tube furnace and reactor, T6-T9 to outlet gas line, inside and at surface temperature and T10 at gas inlet to monitor gas inlet temperature. Pressure (P1, fig. 1) is verified at reactor exit using a mechanical pressure gauge in order to maintain an absolute pressure close to $101.3 \mathrm{kPa}$ in the reactor.

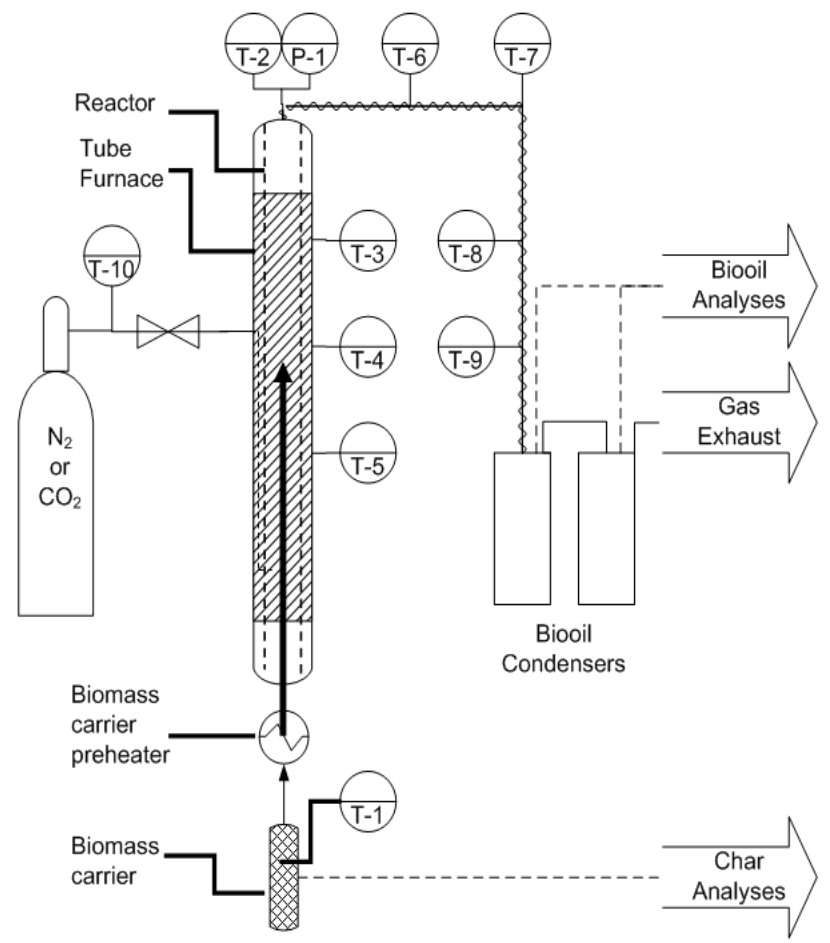

Figure 1: Schematic representation of the experimental setup.

\subsection{Biomass char production and products mass balance}

Biomass was first cut into pieces shorter than $10 \mathrm{~cm}$ and humidity level, which ranged between 4 and 10\%, was monitored all along the char production periods. Typically one gram of switchgrass was inserted in the biomass carrier per batch. For each batch operating at higher heating rates, the biomass carrier was first preheated until reaching reactor's temperature, before being rapidly filled with biomass and inserted in the core of the reactor. This resulted in an almost 
instantaneous heat up of biomass. Gas environment used at higher heating rate is $\mathrm{N}_{2}$. At lower heating rate, a comparison between $\mathrm{N}_{2}$ and $\mathrm{CO}_{2}$ was made. In these latter conditions, the biomass carrier was not preheated, biomass was inserted in the carrier, approached to reactor's opening to flush air and rapidly entered within the reactor. Biomass is kept in reactor for a desired residence time of 2.5 minutes, after what it was removed from the reactor, emptied, its content cooled down within a desiccator and transferred within hermetic containers until further analysis. During experiments at high heating rate, time was monitored from the moment the biomass was inserted in the preheated carrier. For moderate heating rates, time was counted once the temperature reading indicated the desired temperature. It took about 7.5 and $9.5 \mathrm{~min}$. to reach 500 and $300^{\circ} \mathrm{C}$ respectively for slow heating rates conditions. For all batches, tube furnace was maintained at a fixed temperature. Chars were produced at 300 and $500 \pm 10^{\circ} \mathrm{C}$. Chars produced for specific conditions were mixed together before analysis. For moderated heating rate only, a mass balance on products was performed. Bio-oil was collected using condensers and non-condensable gases were determined by difference.

\subsection{Feedstock characterization}

\subsubsection{Proximate analysis and calorific value}

Char as well as original feedstock were both characterized for ash content and volatile content following ASTM E1755-01 and ASTM E 872 methods. Fixed carbon was determined by difference from the ash and volatile content. Higher heating value (HHV) was determined using an oxygen bomb calorimeter; Model 1341 from Parr company.

\subsubsection{Organic elemental analysis}

For CHON organic elemental content analysis, finely powdered feedstock was analyzed using a Leco TruSpec Micro CHNS equipped with the TruSpec Micro Oxygen Add-On Module for oxygen analysis.

\subsubsection{BET analyses}

Biomass samples were first sieved and the range between 40 and 60 mesh was used for BET analyses. Surface area characterization was performed using Micromeritic physical adsorption apparatus, ASAP 2020, using nitrogen adsorption based on BET theory. Degas conditions were done under vacuum from an initial heating rate of $10^{\circ} \mathrm{C} / \mathrm{min}$ up to a temperature of $110^{\circ} \mathrm{C}$ kept for a minimum of 16 hours.

\subsubsection{Organic components, extractions and GC-MS analysis}

Char organic components extraction was done using Soxhlet. These tests were conducted on high heating rate chars only. Prior to Soxhlet extractions, char was grinded to a fine powder. For each extraction, one gram of char was placed in Whatman cellulose cartridges $(25 \mathrm{~mm} \mathrm{ID} \times 90 \mathrm{~mm})$ and extracted with $150 \mathrm{ml}$ of dichloromethane. The solution was concentrated using roto-evaporator. Biooils obtained from slow heating rate conditions were also analyzed. These latter 
collected into condensers were diluted into acetone before being injected into GC-MS. The gas chromatogram utilized is a HP 5890 Series II equipped with HP 5971A Mass Selective Detector and HP 7673 Controller.

\section{Results and discussion}

\subsection{Heating rate effect}

At $300^{\circ} \mathrm{C}$, a change in heating rate does not seem to have a major effect on physical properties despite the fact the char yield varied slightly as well as higher heating value (HHV), table 1. Char yield would have been expected to decrease with increased heating rate, as well as volatile content since generally increasing heating rate results in higher liquid yields and lower char yields, as for $500^{\circ} \mathrm{C}$. Perhaps that at lower temperature, this principle does not hold and the longer temperature progression temperature period had a more pronounced effect on char yield. Char yield being lower at $300^{\circ} \mathrm{C}$ is at least consistent with the higher fixed carbon content that may have resulted from longer residence time, releasing more volatiles at temperatures lower than $300^{\circ} \mathrm{C}$. This latter would also explain the increase in heating value content. Higher heating value obtained for $500{ }^{\circ} \mathrm{C}$ in this research is really close to what was previously reported in literature using a bench scale fluidized bed reactor design $(21.5 \mathrm{vs} .18 .6 \mathrm{MJ} / \mathrm{kg})$ [21]. At $500^{\circ} \mathrm{C}$, decreasing heating rate seems to have a pronounced effect on surface area passing from 52 to $82 \mathrm{~m}^{2} / \mathrm{g}$. Effect on biooil content was not observed since biomass carrier preheating step for higher heating rates resulted in some volatiles losses. It has to be kept in mind that oxygen introduction resulting from carrier preheating may have major effect on the results.

\subsection{Gas environment effect}

At $300^{\circ} \mathrm{C}$, gas environment does not seem to have a major effect on physical properties. All parameters studied did not vary, which is consistent to theory mentioning that $\mathrm{CO}_{2}$ is inert at lower temperature [16] (table 1). On the other hand, despite the fact it would require further analyses, presence of compounds such as syringol, methoxyeugenol and palmitic acid was noted in $300^{\circ} \mathrm{C} \mathrm{CO}_{2}$ oils which was not at $300^{\circ} \mathrm{C} \mathrm{N}_{2}$. A further investigation on oil is however required in order to prove that observation.

At $500^{\circ} \mathrm{C}$ though, gas environment seems to have a more pronounced effect. First of all, decrease in char yield and carbon content in presence of $\mathrm{CO}_{2}$ shows that Boudouard reversed reaction could have taken place, resulting in higher carbon conversion and gas yield. Since $500^{\circ} \mathrm{C}$ is a relatively low temperature for Boudouard reaction to take place, it seems that at least an element acted as a catalyst. It this case, two factors may be the catalyst source: the first could be $\mathrm{Ni}$ element present in stainless steel of the reactor, the thermocouple and the biomass carrier. As reported by Osaki and Mori [22], in presence of $\mathrm{Ni}$, the reversed Boudouard reaction along gasification operates at same rate at $500^{\circ} \mathrm{C}$ than without catalyst at $800^{\circ} \mathrm{C}$. The second factor could come from the high ash 
content into switchgrass that could act as catalyst for Boudouard reversed reaction. Butterman and Castaldi [15] observed that activation energy for pyrolysis and gasification in $\mathrm{CO}_{2}$ atmosphere was lowered in presence of herbaceous feedstock in comparison to wood. This difference was attributed mostly to higher ash content in herbaceous feedstock than for wood.

Specific surface is also another parameter which was influenced by carbon dioxide. At $300{ }^{\circ} \mathrm{C}$ there was no change noticed, however at $500^{\circ} \mathrm{C}$, specific surface passed from 82 to $189 \mathrm{~m}^{2} / \mathrm{g}$, (table 1), which is consistent to results from Jindarom et al. [16] who observed a drastic change in specific surface from $550^{\circ} \mathrm{C}$.

\subsection{Temperature effect}

Temperature treatments add a pronounced effect on surface area. Increasing temperature from 300 to $500^{\circ} \mathrm{C}$ increased surface area from less than $1 \mathrm{~m}^{2} / \mathrm{g}$ for all $300^{\circ} \mathrm{C}$ char production studied, to more than $50 \mathrm{~m}^{2} / \mathrm{g}$ at high heating rate and to more than $80 \mathrm{~m}^{2} / \mathrm{g}$ at low heating rate, table 1 . Despite the fact the high increase in surface area at $500^{\circ} \mathrm{C}$ might be beneficial on a soil amendment application, the decrease in char yield passing from about $68 \%$ to $14 \%$ must be considered among the economics of the process depending on the application. Char yield from 66 to $70 \%$ at $300^{\circ} \mathrm{C}$ could result mostly from hemicellulose decomposition as reported by Prins et al. [8]. This latter assumption would be consistent with switchgrass hemicelluloses content which was estimated at $36.3 \%$, table 2 . In each case, char yield decreased with increasing temperature with respect to specific factors studied. This mass balance is consistent with observations made by other authors showing that cellulose decomposition occurs at temperature from 305 to $375^{\circ} \mathrm{C}$ and lignin at temperature from 250 to $500^{\circ} \mathrm{C}$ [8]. Switchgrass cellulose content represents $33.7 \%$ of biomass composition (table 2), lignin being more reluctant to decomposition, this latter would then potentially balance the remaining losses. Boateng et al. [21] worked on the same species using a bench-scale fluidized bed fast pyrolysis reactor. They run their tests at a temperature of $500^{\circ} \mathrm{C}$ and the char produced corresponded to $12.9 \%$ of the original biomass, which is close to the actual values obtained [21].

It has to be noted that char was removed from the reactor once the residence time was completed. As a result, for higher temperature, $500^{\circ} \mathrm{C}$, the biomass and biomass carrier remain at temperature high enough for char reacting with the ambient oxygen, resulting in char glowing red. This definitively may have an effect on char yields by reducing it as well as an effect on its characteristics.

\subsection{DCM extractions and analyses}

Char organic content using Soxhlet extractions with dichloromethane were used to investigate if PAHs would be present within the char studied. This study was completed only for the high heating rate and within the studied conditions, only naphthalene was qualitatively noticed at $500^{\circ} \mathrm{C}$ temperature. In literature, operating temperature increase was already reported to increase PAH formation 


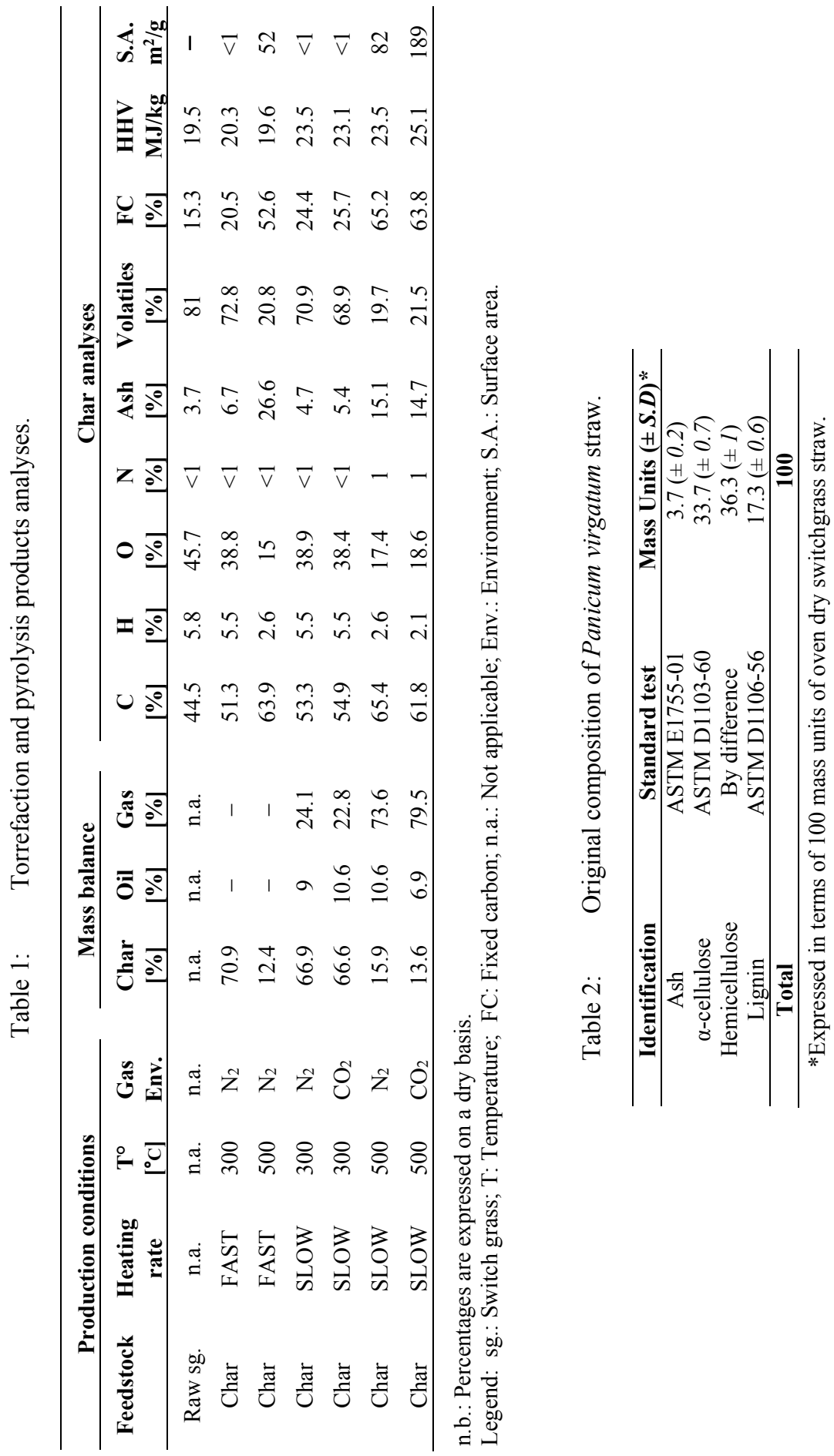


$[23,24]$. Since extractions requires substantial amount of char in order to be extracted, further investigation of such parameter will be carried using a reactor with higher feedstock capacity.

\section{Conclusion}

Preliminary investigations of char formation from switchgrass show results similar to those reported so far. Lowering the heating rate would enhance the specific char surface area especially at $500^{\circ} \mathrm{C}$. It would also result in slightly higher char yield, which may be beneficial from a production point of view. Carbon dioxide showed to have a great impact on specific surface at $500^{\circ} \mathrm{C}$, leading to a specific surface of $189 \mathrm{~m}^{2} / \mathrm{g}$, which more than doubled the $\mathrm{N}_{2}$ results. For a biochar-soil amendment application, where optimized yields are desired as well as high specific surface, residual $\mathrm{CO}_{2}$ might then represent a strong potential since the yield compared to $500^{\circ} \mathrm{C} \mathrm{N}_{2}$ was reported as similar. Leaching of ashes prior to pyrolysis or using a reactor free of $\mathrm{Ni}$ could be recommended in further experiments in order to target whether an element or another was responsible for the enhancement of $\mathrm{CO}_{2}$ effect. Despite the fact $\mathrm{CO}_{2}$ seems to be inert at $300^{\circ} \mathrm{C}$ based on physical characteristics of chars, preliminary results for biooil content analysis revealed some differences which must be further investigated. Further investigation about chemical composition of char obtained under $500^{\circ} \mathrm{C}$ would also be interesting since the appearance of PAHs occurred at higher heating rates with $\mathrm{N}_{2}$, however in presence of $\mathrm{CO}_{2}$, the content could potentially be reduced since char tar content could react with $\mathrm{CO}_{2}$ and enhance $\mathrm{CO}$ formation. It was also reported that final reacting conditions at open atmosphere resulted in decrease of char yield. Despite the fact this obvious reaction with oxygen could easily be reduced by waiting for char to cool down, the effect of such post treatment on char properties should also be analyzed further with respect to char value additions and the practical applications of the technology.

\section{Acknowledgements}

The authors would like to thank Le Fonds québécois de la recherche sur la nature et les technologies (FQRNT) as well as the Université de Sherbrooke, Faculty of Engineering and Department of Chemical Engineering, for the financial support for Guillaume Pilon's PhD thesis; the Université de Sherbrooke, the Faculty of Engineering and the Department of Chemical Engineering and Biotechnological Engineering for supporting this research (through starting funds for Jean-Michel Lavoie and lending research equipment) as well as the Industrial Chair in Ethanol Cellulosic in lending research equipment. The authors would also like to acknowledge Ms. Eva Capek, Mr. Henri Gauvin, Mr. Serge Gagnon, Mr. Marc G. Couture and Mr. Michel Trottier of the Université de Sherbrooke for their technical support. Finally, Mr. Daniel Clément, switchgrass producer from the Eastern Township, for providing the feedstock for the experiments. 


\section{References}

[1] Lehmann, J. \& Joseph, S., Biochar for Environmental Management, Earthscan: London - Washington, DC, 2009.

[2] McLaughlin, H., Anderson, P.S., Shields, F.E. \& Reed, T.B., All biochars are not created equal, and how to tell them apart. North American Biochar Conference, 2009.

[3] Gaunt, J.L. \& Lehmann, J., Energy balance and emissions associated with biochar sequestration and pyrolysis bioenergy production. Environmental Science \& Technology, 42(11), pp. 4152-4158, 2008.

[4] Lehmann, J., A handful of carbon. Nature, 447(7141), pp. 143-144, 2007.

[5] Laird, D.A., The charcoal vision: a win win win scenario for simultaneously producing bioenergy, permanently sequestering carbon, while improving soil and water quality. Agronomy Journal, 100(1), pp. 178-181, 2008.

[6] Boateng, A.A., Characterization and thermal conversion of charcoal derived from fluidized-bed fast pyrolysis oil production of switchgrass. Industrial and Engineering Chemistry Research, 46(26), pp. 8857-8862, 2007.

[7] Uslu, A., Faaij, A.P.C. \& Bergman, P.C.A., Pre-treatment technologies, and their effect on international bioenergy supply chain logistics. Technoeconomic evaluation of torrefaction, fast pyrolysis and pelletisation. Energy, 33(8), pp. 1206-1223, 2008.

[8] Prins, M.J., Ptasinski, K.J. \& Janssen, F.J.J.G., Torrefaction of wood: Part 1. Weight loss kinetics. Journal of Analytical and Applied Pyrolysis, 77(1), pp. 28-34, 2006.

[9] Brewer, C.E., Schmidt-Rohr, K., Satrio, J.A. \& Brown, R.C., Characterization of biochar from fast pyrolysis and gasification systems. Environmental Progress \& Sustainable Energy, 28(3), pp. 386-396, 2009.

[10] Mohan, D., Pittman, C.U. \& Steele, P.H., Pyrolysis of wood/biomass for bio-oil: a critical review. Energy \& Fuel, 20(3), pp. 848-889, 2006.

[11] Joseph, S., Peacocke, C., Lehmann, J. \& Munroe, P., Developing a biochar classification and tests methods (Chapter 7). Biochar for Environmental Management - Science and Technology, ed. J. Lehmann \& S. Joseph, Earthscan: London and Washington DC, pp. 107-112, 2009.

[12] Downie, A., Crosky, A. \& Munroe, P., Physical Properties of Biochar, Biochar for Environmental Management - Science and Technology. ed. J. Lehmann \& S. Joseph, Earthscan: London and Washington DC, pp. 1329, 2009.

[13] Demirbas, A., Carbonization ranking of selected biomass for charcoal, liquid and gaseous products. Energy Conversion and Management, 42(10), pp. 1229-1238, 2001.

[14] Buhre, B.J.P., Elliott, L.K., Sheng, C.D., Gupta, R.P. \& Wall, T.F., Oxyfuel combustion technology for coal-fired power generation. Progress in Energy and Combustion Science, 31(4), pp. 283-307, 2005. 
[15] Butterman, H.C. \& Castaldi, M.J., Biomass to fuels: impact of reaction medium and heating rate. Environmental Engineering Science, 27(7), pp. 539-555, 2010.

[16] Jindarom, C., Meeyoo, V., Kitiyanan, B., Rirksomboon, T. \& Rangsunvigit, P., Surface characterization and dye adsorptive capacities of char obtained from pyrolysis/gasification of sewage sludge. Chemical Engineering Journal, 133(1-3), pp. 239-246, 2007.

[17] Minkova, V., Marinov, S.P., Zanzi, R., Björnbom, E., Budinova, T., Stefanova, M. \& Lakov, L., Thermochemical treatment of biomass in a flow of steam or in a mixture of steam and carbon dioxide. Fuel Processing Technology, 62(1), pp. 45-52, 2000.

[18] Sharma, R.K., Wooten, J.B., Baliga, V.L., Lin, X., Geoffrey Chan, W. \& Hajaligol, M.R., Characterization of chars from pyrolysis of lignin. Fuel, 83(11-12), pp. 1469-1482, 2004.

[19] He, R., Ye, X.P., English, B.C. \& Satrio, J.A., Influence of pyrolysis condition on switchgrass bio-oil yield and physicochemical properties. Bioresource Technology, 100(21), pp. 5305-5311, 2009.

[20] Martel, H. \& Perron, M.-H., Compilation des essais de Panic Érigé réalisés au Québec. Centre de référence en agriculture et agroalimentaire du Québec, 2008. http://www.craaq.qc.ca/data/DOCUMENTS/EVC026.pdf

[21] Boateng, A.A., Daugaard, D.E., Goldberg, N.M. \& Hicks, K.B., BenchScale fluidized-bed pyrolysis of switchgrass for bio-oil production. Industrial \& Engineering Chemistry Research, 46(7), pp. 1891-1897, 2007.

[22] Osaki, T., \& Mori, T., Kinetics of the reverse-Boudouard reaction over supported nickel catalysts. Reaction Kinetics and Catalysis Letters, 89(2), pp. 333-339, 2006.

[23] McGrath, T., Sharma, R. \& Hajaligol, M., An experimental investigation into the formation of polycyclic-aromatic hydrocarbons (PAH) from pyrolysis of biomass materials. Fuel, 80(12), pp. 1787-1797, 2001.

[24] Nakajima, D., Nagame, S., Kuramochi, H., Sugita, K., Kageyama, S., Shiozaki, T., Takemura, T., Shiraishi, F. \& Goto, S., Polycyclic aromatic hydrocarbon generation behaviour in the process of carbonization of wood. Bulletin of Environmental Contamination and Toxicology, 79(2), pp. 221-225, 2007. 